\title{
PHYTOCHEMICAL, ANTIBACTERIAL, ANTIOXIDANT AND ANTICANCER ACTIVITY STUDY OF M. candidum LEAF ACETONE EXTRACT
}

\author{
Tita Juwitaningsih ${ }^{1, *}$, Iis Siti Jahro ${ }^{1}$, Ida Dumariris ${ }^{1}$, Elvira Hermawati ${ }^{2}$ \\ and Yaya Rukayadi ${ }^{3}$ \\ ${ }^{1}$ Department of Chemistry, Faculty of Mathematics and Natural Sciences, Universitas Negeri \\ Medan, Jl. Willem Iskandar, Pasar V Medan Estate, Medan 20221, North Sumatera, Indonesia \\ ${ }^{2}$ Organic Chemistry Division, Faculty of Mathematics and Natural Sciences, Institut Teknologi \\ Bandung, Jalan Ganesha 10, Bandung 40132, Indonesia \\ ${ }^{3}$ Lab. of Natural Products, Institute of Bioscience, Universiti Putra Malaysia, 43400 UPM \\ Serdang, Selangor Darul Ehsan, Malaysia \\ *E-mail:juwitaningsih@gmail.com
}

\begin{abstract}
M. Candidum has been frequently used as a traditional medicine to treat various diseases such as diarrhea, dysentery, haemorrhoids, cuts and wounds, toothache, and stomach ache. This research was aimed to identify the activity of M. candidum acetone extract as an antibacterial, antioxidant, anticancer and phytochemical. Antibacterial activity test was performed in vitro against each of the two Gram-positive and Gram-negative bacteria by paper disc diffusion method followed by determination of the minimum inhibitory concentration (MIC) and minimum bactericidal concentration (MBC) values. The antioxidant activity of the extract was tested against 2,2-diphenyl1picrylhydrazyl (DPPH), while the cytotoxic activity of the extract was evaluated against MCF-7 cells. Furthermore, the identification of secondary metabolite content was determined by ${ }^{1} \mathrm{H}-\mathrm{NMR}$ spectroscopy. Activity test results revealed that acetone extract of M.Candidum leaf was activite against four pathogenic bacteria, such as $P$. acne ATCC (27853), S. saprophyticus ATCC (49907), S. Mutans ATCV (35668), C. freundii ATCC 8090) with inhibition diameter of $5.70 \pm 0.17-11.23 \pm 0.23$ with MIC values of $1250-2500 \mu \mathrm{g} / \mathrm{mL}$ and MBC between $1250-$ $>5000 \mu \mathrm{g} / \mathrm{mL}$. M.candidum acetone extract has antioxidant and cytotoxic activity with $\mathrm{IC}_{50}$ value $=22.4761 \mu \mathrm{g} /$ $\mathrm{mL}$ and $\mathrm{IC}_{50}=601.09 \mathrm{ug} / \mathrm{mL}$ respectively. Also, the results of phytochemical tests indicated that M. candidum acetone extract contained terpenoids and aromatic compounds.
\end{abstract}

Keywords: M. candidum, Antibacterial, Antioxidant, Anticancer, Phytochemical.

(C) RASĀYAN. All rights reserved

\section{INTRODUCTION}

Natural compounds play an important role in the development of medicinal substances. Many compounds that came from natural ingredients have transformed into drug candidates, and even most of the drugs used today are derived from natural compounds, such as Ouinine, theophylline, penicillin G, morphine, paclitaxel, digoxin, vincristine, doxorubicin, cyclosporin, and vitamin A. ${ }^{1}$ One of the approaches used to obtain natural compounds that have potential as medicinal compounds are performed through the assessment of potentially therapeutic plants through the ethnopharmacology approach. ${ }^{2}$

Plants of the Melastomataceae family are widely used for traditional medicine. Currently, the number of Melastoma species has not been exactly reported, however, an estimation has been reported to be 80-90 species. ${ }^{3}$ In the Southeast Asia region, the genus Melastoma consists of 22 species, ${ }^{4}$ one of which is Melastoma candidum that is commonly used as a medicinal plant in North Sumatra, Indonesia. M. candidum has the local name of "Senduduk" and the synonym name of Melastoma malabathrum subsp. normale (D. Don) K.Mey, Melastoma polyanthum Blume. M. candidum is an easy plant to grow and is commonly found in the province of North Sumatra, Indonesia. In North Sumatra, especially for Karo ethnicity, the M.candidum plant has been used as a traditional medicine to treat abscesses, thrush, Rasayan J. Chem., 13(2), 1096-1103(2020)

http://dx.doi.org/10.31788/RJC.2020.1325614 
diarrhea, bone fractures and oukup. ${ }^{5,6}$ In addition to Bangladesh, India and Malaysia, M.candidum has been used to treat diarrhea, dysentery, haemorrhoids, cuts and wounds, toothache, and stomach ache. ${ }^{4}$

M.candidum, as traditional medicine is widely known, that several studies have been carried out to investigate it. In detail, M.candidum plant extract has various pharmacological effects, such as antibacterial, antiviral, anti-parasitic, antioxidant, cytotoxicity, anticoagulant, platelet-activating factor inhibitory, wound healing, anti-ulcer, anti-diarrheal, anti-venom, anti-inflammatory,anti-nociceptive, and anti-pyretic. ${ }^{4,7}$ Therefore, this research was aimed to observe and report the potential of M.candidum plant, which is commonly found in North Sumatra, as an antibacterial agent, antioxidant, anticancer based on its phytochemical test.

\section{Plants extract Preparation}

\section{EXPERIMENTAL}

Samples of M. candidum were obtained from herbal drug stores, CV. Sempurna Sambu, Medan, Indonesia. A total of $100 \mathrm{~g}$ of the dried sample was mashed, and then extracted by maceration process using a $500 \mathrm{~mL} 100 \%(\mathrm{v} / \mathrm{v})$ acetone solvent for $3 \times 24$ hours at room temperature. Then, it was filtered with Whatman filter paper no.2 (Whatman International Ltd, Middlesex, England). The filtrate was evaporated at low pressure using a rotary evaporator (Heidolph VV 2011, Schwabach, Germany) at a temperature of $50^{\circ} \mathrm{C}$, until the crude extract was obtained.

\section{Antibacterial Agents}

As much as $100 \mathrm{~g}$ of M.candidum extract was dissolved in $1 \mathrm{~mL}$ DMSO. Then, it was diluted 10 times to obtain a $1 \%$ solution in $10 \%$ DMSO (Sigma Aldrich), which was equivalent to $10,000 \mu \mathrm{g} / \mathrm{mL}$. Also, chloramphenicol $(500 \mu \mathrm{g} / \mathrm{mL})$ was used as an antibiotic standard.

\section{Antibacterial Strains and Inoculums Preparation}

The four American Type Culture Collection bacteria used for the test bacteria consisted of two Grampositive bacteria: Propionibacterium acne ATCC (27853), Staphylococcus saprophyticus ATCC (49907), and two Gram-negative bacteria: Streptococcus mutans ATCV (35668) and Citrobacter freundii ATCC 8090. The inoculum was prepared based on the growth method by taking 3-5 isolated bacterial colonies with the same morphological type from the culture plate and a sterilized cotton bud was used. Then, it was suspended to $4-5 \mathrm{~mL}$ of $0.9 \% \mathrm{NaCl}$. Furthermore, the turbidity of the suspension was adjusted to the turbidity of $0.5 \mathrm{Mc}$.Farland.

\section{Antibacterial Activity}

M02-A11 paper disc diffusion method with Clinical and Laboratory Standards Institute Reference method (CLSI) was used for a preliminary test. A total of $100 \mu \mathrm{L}$ inoculums of bacterial species were added to the Mueller Hinton Agar (MHA) plate evenly, using a sterile spreader. Then, the sterile paper disk blank (6 mm diameter disc, oxoid) was placed on the surface of the inoculum layer on the MHA plate in an even manner. After that, a total of $15-20 \mu \mathrm{L}$ of the test solution was dripped on paper discs, then aerobically incubated at $37^{\circ} \mathrm{C}$ for 24 hours. ${ }^{8}$

\section{Determination of Minimum Inhibitory Concentration (MIC) Value}

The microdilution method (M07-A9) was used for the determination of MIC, using a microplate (96well). ${ }^{9}$ The first well was filled with Muller Hinton Broth (MHB, oxoid) media which served as a negative control. The second well was filled with media and inoculum as a positive control. Wells 3 to 12 were filled with a series of sample concentrations. In each microplate well, as much as $100 \mu \mathrm{L}$ of MHB liquid media containing inoculum was inserted. Into well 12 , a total of $100 \mu \mathrm{L}$ MHB liquid was inserted and moved to well 11. A similar step was performed towards well 11 to well 3 , resulting in an equal amount of MHB liquid. Lastly, microplate was incubated at $37^{\circ} \mathrm{C}$ for 24 hours. ${ }^{10}$

\section{Determination of Minimum Bactericidal Concentration (MBC)}

MBC determination was conducted according to to ${ }^{11,12}$. Each of $10 \mu \mathrm{L}$ mixture in each well on the micro plate of MIC test results was inoculated into the MHA plate. The MHA plate was incubated at $37^{\circ} \mathrm{C}$ for 24 hours or until the growth was seen in positive control. 
RASĀYAN J. Chem.

Vol. 13 | No. 2 |1096 - 1103| April - June | 2020

\section{Antioxidant Activity Test}

Antioxidant activity tests were carried out following. ${ }^{13,14}$ The sample was reacted with DPPH, and then left for 30 minutes. Then, it was analyzed by UV-Vis spectrophotometer at a wavelength of $517 \mathrm{~nm}$. Methanol was used as a blank and the absorbance value of each concentration variation was recorded along with the $\mathrm{IC}_{50}$ value.

\section{Cytotoxic Testing of MCF7 Cells}

The cytotoxic activity test was carried out by the method as described by ${ }^{14}$ with a slight modification, namely the positive control used in this test was Cisplatin and the use of presto blue reagent.

\section{Cell Inhibition Percentage}

The percentage of cell inhibition from each sample concentration obtained was calculated by using a formula as follows:

$$
\% \text { Inhibition }=[(\text { Absorbance Control- Absorbance Sample }) /(\text { Absorbance Control })]
$$

\section{Phytochemical Test}

Phytochemical analysis was performed by NMR spectroscopy. The ${ }^{1} \mathrm{H}-\mathrm{NMR}$ spectrum was determined with the Agilent DD2 spectrometer which operates at $500 \mathrm{MHz}\left({ }^{1} \mathrm{H}\right)$.

\section{Antibacterial Activity}

\section{RESULTS AND DISCUSSION}

Antibacterial activity test was carried out in vitro and the preliminary test was performed using the paper disc diffusion method.MHA media (Mueller Hinton Agar) as recommended by CLSI, FDA and WHO was used for antibacterial testing. This agar media has also been shown to provide good and reproducible results for Davis and Stout. ${ }^{15}$ The potential antibacterial properties of the extract were determined from the clear zone around the filter paper as displayed in Fig.-1.

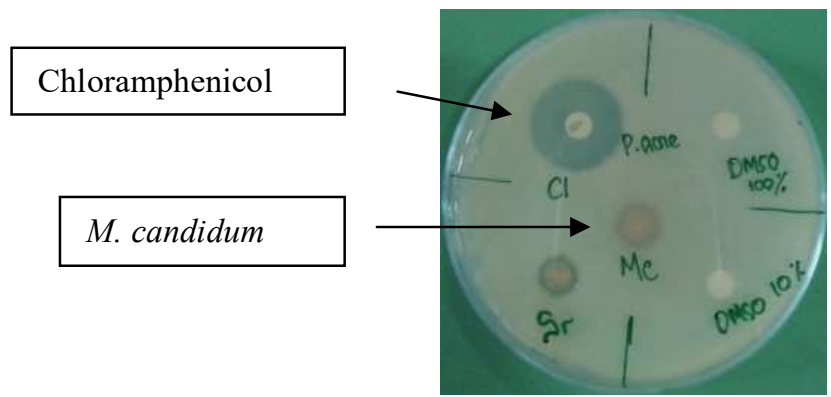

Fig.-1: Clear Zone Diameter of M. Candidum extract towards P. Acne

Preliminary test of the antibacterial activity against the extract of $M$. candidum acetone was conducted by using the disk diffusion method. The test results showed the existence of antimicrobial activity against four bacteria tested with inhibition zone diameters between $5.7 \pm 0.17 \mathrm{~mm}-11.23 \pm 0.23 \mathrm{~mm}$. Inhibition test data are summarized in Table-1.

Table-1: The Antibacterial Activity of Acetone Extracts of M. Candidum by Disc Diffusion Method

\begin{tabular}{c|c|c|c}
\hline Gram-positive Bacteria & Diameter \pm SD $(\mathrm{mm})$ & Gram-negative Bacteria & Diameter \pm SD (mm) \\
\hline $\begin{array}{c}\text { P.acne } \\
\text { ATCC (27853) }\end{array}$ & $11.23 \pm 0.2082$ & $\begin{array}{c}\text { S.mutans } \\
\text { ATCV }(35668)\end{array}$ & $10.26 \pm 0.1157$ \\
\hline S. saprhophyticus ATCC (49907) & $7.53 \pm 0.256$ & $\begin{array}{c}\text { C. Freendii } \\
\text { ATCC (8090) }\end{array}$ & $5.7 \pm 0.1723$ \\
\hline
\end{tabular}

Based on Table-1, M.candidum extract showed activity against all test bacteria. The tendency of antibacterial activity test of M.candidum extract was in line with the results of a study conducted by ${ }^{16}$. 
RASĀYAN J. Chem.

Vol. 13 | No. 2 |1096 - 1103| April - June | 2020

There are two types of antibacterial activity, namely bacteriostatic and bactericidal. Bacteriostatic is inhibiting bacterial growth while bactericidal is killing bacteria. The determination of the MIC value was intended to determine the lowest inhibitory concentration of a bacterium. On the other hand, the determination of $\mathrm{MBC}$ was intended to determine the lowest concentration of killing a bacterium. Micro dilution method was used for MIC and MBC determination. Acetone extract of M.candidum can inhibit bacterial growth with an MIC range between $625-2500(\mu \mathrm{g} / \mathrm{mL})$. While the concentration of extract to kill bacteria was in the range between 1250-> $5000(\mu \mathrm{g} / \mathrm{mL})$. Data on MIC and MBC values are summarized in Table-2.

Table-2: MIC and MBC Values of M. Candidum Acetone Extract

\begin{tabular}{c|c|c|c|c}
\hline \multirow{2}{*}{ Bacteria } & \multicolumn{2}{|c|}{ M. candidum } & \multicolumn{2}{c}{ Chloramphenicol } \\
\cline { 2 - 5 } & $\mathrm{MIC}(\mu \mathrm{g} / \mathrm{mL})$ & $\mathrm{MBC}(\mu \mathrm{g} / \mathrm{mL})$ & $\mathrm{MIC}(\mu \mathrm{g} / \mathrm{mL})$ & $\mathrm{MBC}(\mu \mathrm{g} / \mathrm{mL})$ \\
\hline $\begin{array}{c}\text { S. sapropyticus } \\
\text { ATCC }(49907)\end{array}$ & 2500 & 2500 & 0.48 & 56.30 \\
\hline P.acneATCC(27853) & 1250 & $>5000$ & 0.48 & 31.50 \\
\hline S. MutansATCV(35668) & 1250 & 5000 & 0.97 & 125 \\
\hline C.freundi ATCC $(8090)$ & 2500 & $>5000$ & 1.90 & 62.50 \\
\hline
\end{tabular}

An extract can be categorized as active, moderate and weak if the MIC value was less than $100 \mu \mathrm{g} / \mathrm{mL}$, range of $100<$ MIC $<625 \mathrm{ug} / \mathrm{mL}$, and more than $625 \mu \mathrm{g} / \mathrm{mL}$ respectively. ${ }^{17}$ Thus, $S$. MutansATCV 35668, S. sapropyticusATCC 49907, P.acneATCC 27853 and C.freundi ATCC 8090 were included in a weak category. These results are in line with studies of the MIC values of water extract, ethyl acetate and benzene against E. coli (MDR), S. aureus (MDR), K. pneumonia, B. cereus, V. cholera in the range of $650-800 \mu \mathrm{g} / \mathrm{mL}$ with the weak category and $\mathrm{MBC}$ value of the three extracts against the bacteria were in the range of $700-950 \mu \mathrm{g} / \mathrm{mL}^{16}$

\section{Antioxidant}

The determination of antioxidant activity was performed based on $\mathrm{IC}_{50}$ values (inhibition concentration 50 ). $\mathrm{IC}_{50}$ is a concentration that is needed to inhibit free radicals by $50 \%$. The absorbance measurement results are summarized in Table-3 and displayed in Fig.-2.

Table-3: Anti-oxidant Activity Test using DPPH Method towards M. candidum Acetone Extract

\begin{tabular}{c|c|c|c|c|c}
\hline \multirow{2}{*}{$\begin{array}{c}\text { Concentration } \\
(\mathrm{ppm})\end{array}$} & \multicolumn{2}{|c|}{ Absorbance } & \multicolumn{2}{c|}{$\%$ Inhibition } & \multirow{2}{*}{$\mathrm{IC}_{50}(\mathrm{ppm})$} \\
\cline { 2 - 5 } & Trial-1 & Trial-2 & Trial-1 & Trial-2 & \\
\hline 0 & 0.9333 & 0.8765 & 0.0000 & 0.0000 & \\
\hline 5 & 0.8128 & 0.7976 & 12.9112 & 9.0017 & \\
\hline 10 & 0.7096 & 0.7000 & 23.9687 & 20.1369 & 22.4761 \\
\hline 15 & 0.6127 & 0.5911 & 34.3512 & 32.5613 & \\
\hline 20 & 0.5191 & 0.5011 & 44.3802 & 42.8294 & \\
\hline 25 & 0.4125 & 0.3793 & 55.8020 & 56.7256 & \\
\hline
\end{tabular}

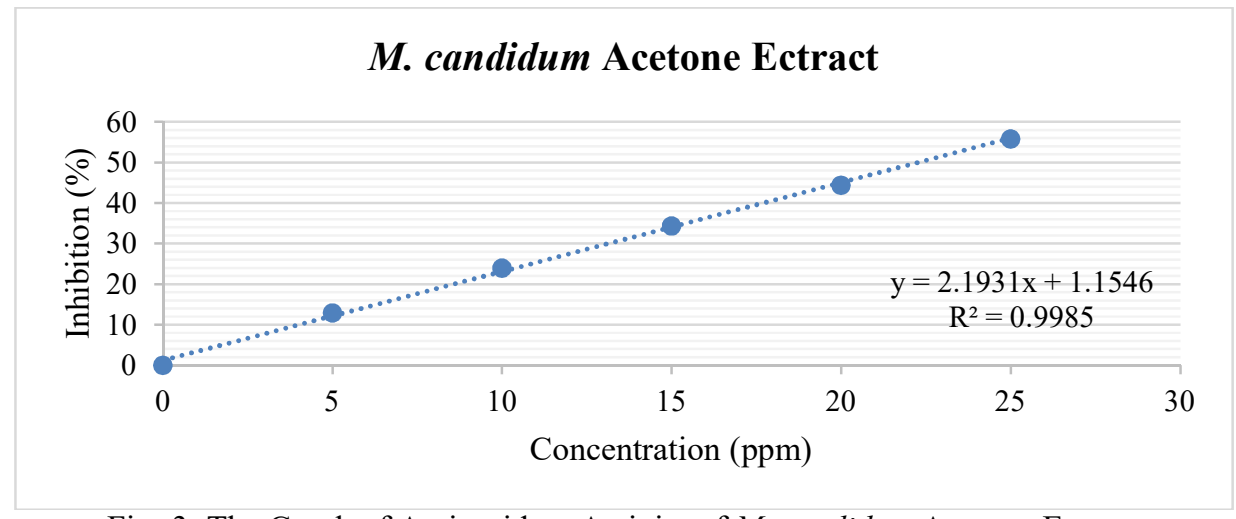

Fig.-3: The Graph of Anti-oxidant Activity of M. candidum Acetone Extract 
RASĀYAN J. Chem.

Vol. 13 | No. 2 |1096 - 1103| April - June | 2020

An antioxidant is categorized as very strong, strong and moderate if the $\mathrm{IC}_{50}$ value is $<50 \mu \mathrm{g} / \mathrm{mL}, 50-100$ $\mu \mathrm{g} / \mathrm{mL}$, and $101-250 \mu \mathrm{g} / \mathrm{mLrespectively.}{ }^{18}$ Based on these criteria, the antioxidant activity of M.candidum acetone extract is categorized as very strong with $\mathrm{IC}_{50}$ value of $22.4761 \mu \mathrm{g} / \mathrm{mL} .{ }^{19,20}$ There is a slight difference in $\mathrm{IC}_{50}$ value from previous researches, because the solvents used to extract are different, so the extracted metabolites were not the same.

\section{Anti-cancer}

The results of absorbance measurements of M. candidum acetone extract on MCF7 breast cancer cells are described in Table-4.

Table-4: The Absorbance of M. candidum Acetone Extract Test towards MCF7 Cell

\begin{tabular}{c|c|c|c}
\hline \multirow{2}{*}{ Control Cell } & $\begin{array}{c}\text { Sample Concentration } \\
(\mu \mathrm{g} / \mathrm{mL})\end{array}$ & Sample Absorbance & Inhibition (\%) \\
\hline \multirow{4}{*}{0.5299} & 7.81 & 0.6003 & -13.29 \\
\cline { 2 - 4 } & 15.63 & 0.5649 & -6.61 \\
\cline { 2 - 4 } & 31.25 & 0.5614 & -5.95 \\
\cline { 2 - 4 } & 62.50 & 0.5183 & 2.20 \\
\cline { 2 - 4 } & 125.00 & 0.4885 & 7.81 \\
\cline { 2 - 4 } & 250.00 & 0.4211 & 20.53 \\
\cline { 2 - 4 } & 500.00 & 0.2660 & 49.81 \\
\cline { 2 - 4 } & 1000.00 & 0.0977 & 81.55 \\
\hline
\end{tabular}

Based on data described in Table-4, a linier regression graph can be produced and resulting in an equation of $\mathrm{y}=0,0937 \mathrm{x}-6,3224$ (Fig.-3). Thus, based on the equation, $\mathrm{IC}_{50}$ value was obtained to be 601.09 $\mu \mathrm{g} / \mathrm{mL}$.

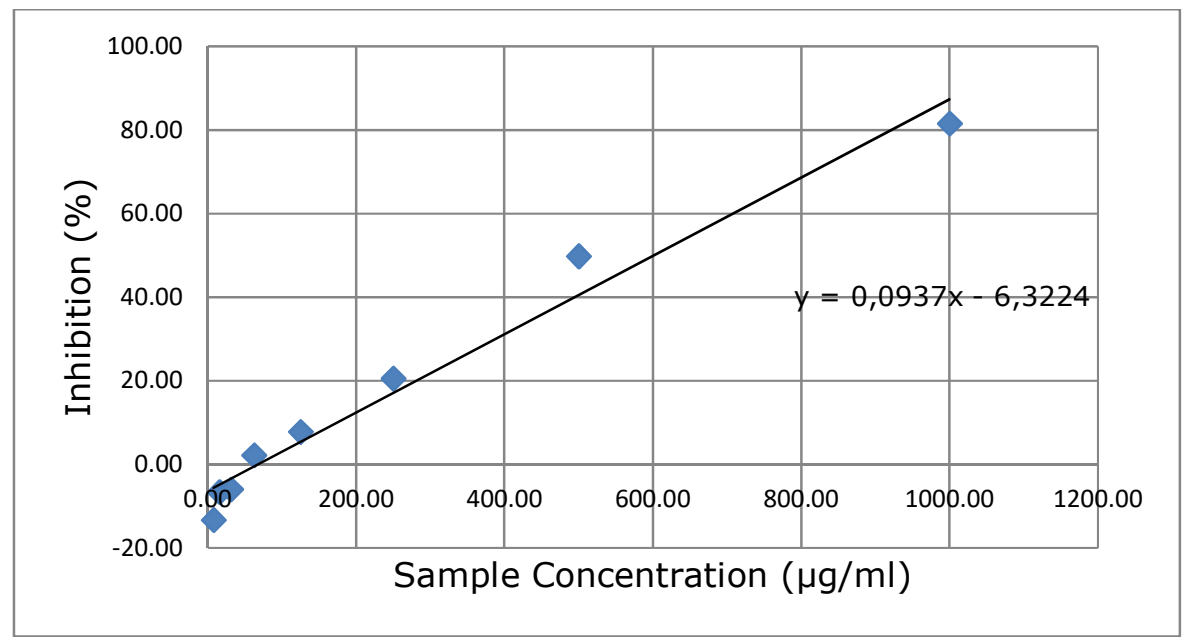

Fig.-3: Absorbance Curve of M. candidum Acetone Extract towards MCF5 Cell

Thus, the acetone extract of $M$. candidum leaves with a concentration of $601.09 \mu \mathrm{g} / \mathrm{mL}$ was able to kill $50 \%$ of MCF7 cells. Based on The National Cancer Institute (NCI), an extract has strong anticancer potential if it has an $\mathrm{IC}_{50}$ value $<30 \mu \mathrm{g} / \mathrm{mL}$, moderate with $30<\mathrm{IC} 50<100 \mu \mathrm{g} / \mathrm{mL}$ and inactive with $\mathrm{IC}_{50}$ value $>100 \mu \mathrm{g} / \mathrm{mL}^{21}$ Therefore, based on these criteria, the acetone extract of $M$. candidum leaves is inactive as an anticancer.

These results are in line with research conducted by ${ }^{22}$ which tested the methanol extract of M.malabatrum leaves on MCF-7 cells and obtained the $\mathrm{IC}_{50}$ values $>400 \mu \mathrm{g} / \mathrm{mLg} / \mathrm{mL}$. The results of this study are also following the results of ${ }^{23}$ who tested the ethyl acetate and methanol extract of M.malabatrum and obtained concentrations of $500 \mu \mathrm{g} / \mathrm{mL}$, causing morphological changes in MCF7 cells. Whereas the 
RASĀYAN J. Chem.

methanol extracts of M.malabatrum did not show anticancer activity. Although the acetone extract of M.candidum leaves is less active against MCF-7 cells, it is still potential as an anticancer based on observations using a microscope (Fig.-4), which shows that at a concentration of $250 \mu \mathrm{g} / \mathrm{mL}$, a huge amount of cells have died, while at concentrations of $500 \mu \mathrm{g} / \mathrm{mL}$, almost all cells were dead. These observation results are indicated from appearing dark, not glowing and the cell membrane looks broken or somewhat faint, while the morphology of living cells appears to shine brilliantly and the membrane boundary with the media is visible.

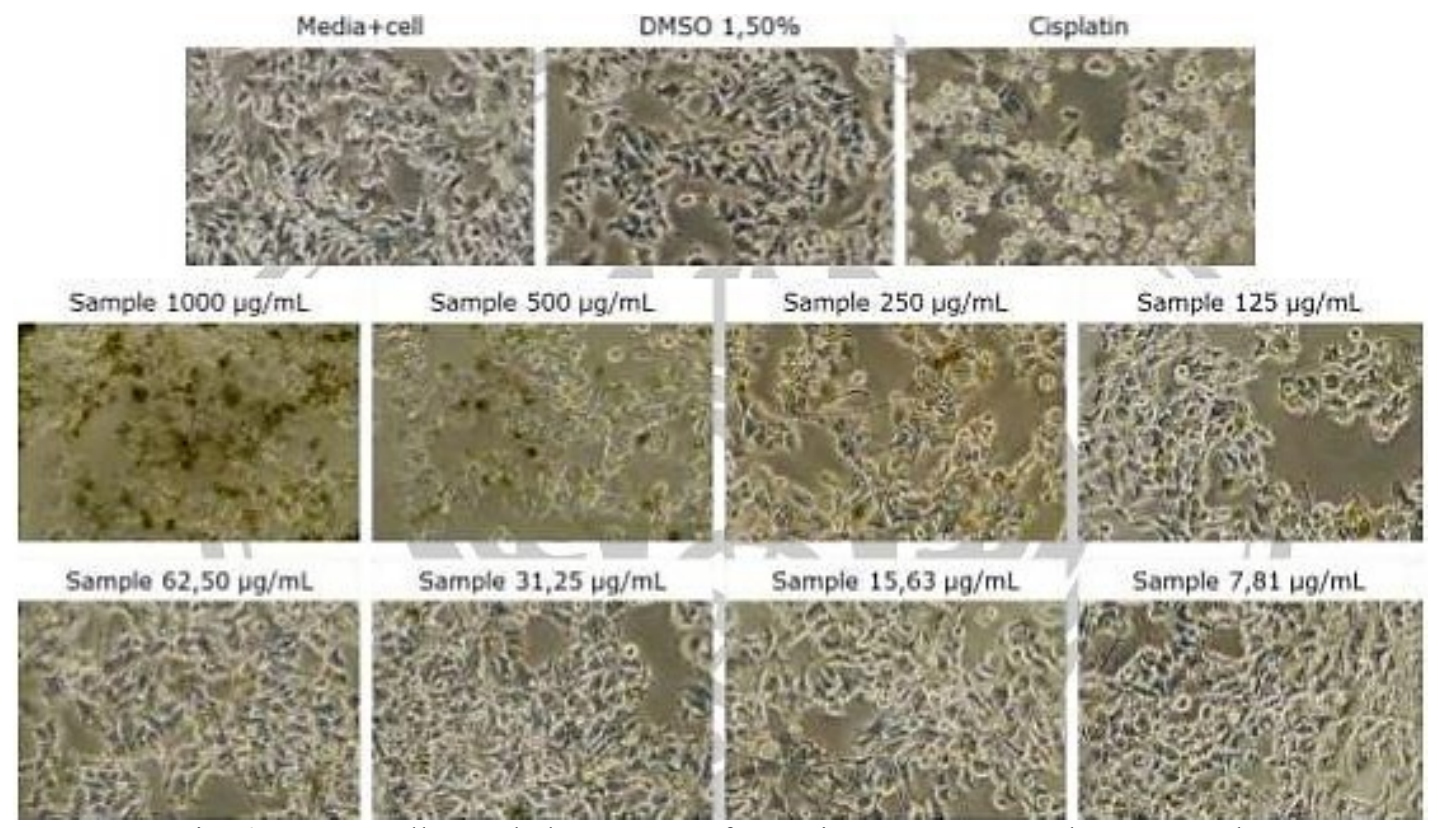

Fig.-4: MCF7 Cell Morphology Images for Various Extract Sample Test Results

\section{Phytochemical Study}

Based on ${ }^{1} \mathrm{H}-\mathrm{NMR}$ data of M.candidum extract with $\mathrm{CD}_{3} \mathrm{OD}$ solvent, a chemical shift $\delta \mathrm{H} 7.5-7.7 \mathrm{ppm}$ (figure 5) which is the signals of aromatic proton benzene derivatives is observed. Signals of $\delta \mathrm{H} 3.1-4.2$ ppm are signals from - $\mathrm{CH}-\mathrm{O}-$ and $\mathrm{C}-\mathrm{OH}$ from a glycoside. Thus, the acetone extract of M.candidum leaves contains aromatic compounds and aromatic compounds that bind a glycoside. From the previous research results, aromatic compounds which were found in M.candidumare including flavanoid and tannins. ${ }^{24}$ Flavonoid compounds that have been successfully isolated from M.candidum extracts were kaempferol, quercetin, narigenin and flavanoid that bind to a glycoside namely Quercitrin, Cyanidin-3glucoside, Cyanidin-3,5-diglucoside, Kaempferol-3-O- $a$-Lrhamnopyranoside, Kaempferol-3-O- $\beta$ Dglucopyranoside,Kaempferol-3-O(2",6"-di-O-p-trnas-coumaryl)- $\beta$-glucoside. Also, tannin was hydrolysed in the form of monomers, dimers, and oligomers, namely 1,4,6-tri- $O$-galloyl- $\beta$-D-glucoside, 1,2,4,6-tetra- $O$-galloyl- $\beta$-D-glucoside, strictinin, casuarictin, pedunculagin, nobotanin $\mathrm{D}$, pterocarinin $\mathrm{C}$, malabathrins (A, B, C,D, E and F), nobotanins B, G, and $\mathrm{H}$ and nobotanin $\mathrm{J}$, casuarinin, (-)epicatechingallate, (-)-epicatechin, stachyurin, procyanidin B-5 and B-2, stenophyllanins A and B, alienanin B, and brevifolincarboxylic acid. ${ }^{4}$

Based on Fig.-5, extracts of M.candidum leaf acetone also contain terpenoid compounds or steroids which are characterized by the presence of a signal at $\delta_{\mathrm{H}} 0.6-2.3 \mathrm{ppm}$. This signal corresponds to $\mathrm{CH}_{3}$ and $\mathrm{CH}_{2}$ groups, which is a characteristic signal of terpenoid or steroid compounds. The terpenoid compounds that have been successfully isolated were including Ursolic acid, 2-Hydroxyursolic acid, Asiatic acid, $\alpha$ Amirin, Uvaol and Bertulinic acid which are triterpenoids. ${ }^{4}$

The medicinal properties of a plant are caused by its secondary metabolite content. Based on the result, M.candidum acetone extract contains aromatic compounds and terpenoids. The compounds act as an antibacterial, antioxidant and anticancer. The mechanism of action of flavonoids in inhibiting bacterial 
RASĀYAN J. Chem.

Vol. 13 | No. 2 |1096 - 1103| April - June | 2020

growth causes damage to bacterial cell wall permeability. ${ }^{25}$ This damages cell membrane, causing the release of various important components from within bacterial cells such as proteins, nucleic acids and nucleotides. While the mechanism of action of terpenoid compounds in inhibiting growth bacteria disrupt the membrane function. ${ }^{26-28}$ Flavanoid is a compound that can donate hydrogen atoms, so that it can reduce the DPPH molecule, thus having the ability as an antioxidant.

Likewise, terpenoids which have hydroxyl groups can donate atoms hydrogen to free radicals. Triterpenoids on the red meranti (Shorea singkawang .Miq) bark tested with DPPH radicals have strong antioxidant activity with $\mathrm{IC}_{50}$ values of $82 \mathrm{ppm} .{ }^{29}$ The failure of $M$. candidum actone extract to exhibit its cytotoxicity effect suggested that the antagonist effect of the compounds presented in the extract play an important role in not affecting the cell proliferation.

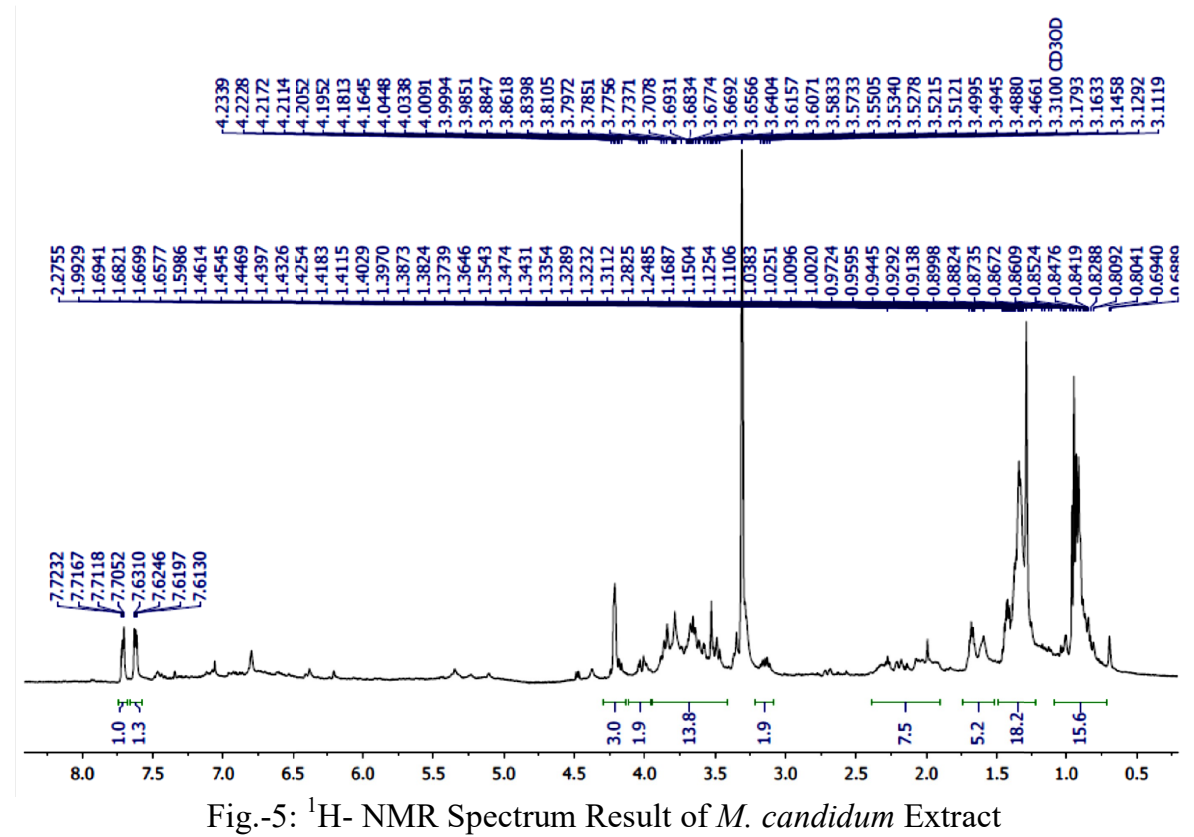

\section{CONCLUSION}

The acetone extract of M.candidum exhibits a broad spectrum of antibacterial activity (both against Gram-positive and Gram-negative bacteria). It also shows a very strong antioxidant activity and potential as an anticancer. Particularly, acetone extract of M.candidum leaves contains aromatic compounds and terpenoids, which can turn M.candidumto be a potential medicinal plant.

\section{ACKNOWLEDGMENT}

The author would like to thank the Ministry of Research, Technology and Higher Education for providing research funding via "Penelitian Dasar Unggulan Perguruan Tinggi (PDUPT), 2019 scheme with contract number of 0190/SP2H/LT/DRPM/2019.

\section{REFERENCES}

1. A.M. Clark, Pharmaceutical Research, 13(8), 1133 (1996), DOI:10.1023/A:1016091631721

2. P.A. Cox, M.J. Balick, Scientific American, 270(6), 82 (1994)

3. K.M. Wong, The Genus Melastoma in Borneo Including 31 New Species. Sabah: Natural History Publications (2016)

4. S.M. Joffry, N.J. Yob, M.S. Rofiee, M.M.R.M.M. Affandi, Z. Suhaili, F. Othman, A.Md. Akim, M.N.M. Desa, Z.A. Zakaria, Evidence-Based Complementary and Alternative Medicine, 2012, 258434 (2012), DOI: 10.1155/2012/258434

5. M. Silalahi, N. Nisyawati, Biodiversitas, 19(1), 229 (2018), DOI:10.13057/biodiv/d190131

6. M. Silalahi, N. Nisyawati, E.B. Walujo, J. Supriatna, W. Mangunwardoyo, Journal of 
Ethnopharmacology, 175, 432 (2015), DOI:10.1016/j.jep.2015.09.009

7. K.C. Wong, D.M. Hag Ali, P.L. Boey, Natural Product Research, 26(7), 609(2012), DOI: $10.1080 / 14786419.2010 .538395$

8. Purwantiningsih, N. Jannah, D.U.C. Rahayu, Rasayan Journal of Chemistry, 13(1), 322(2020), DOI: 10.31788/RJC.2020.1315484

9. T. Juwitaningsih, L.D. Juliawaty, Y.M. Syah, Natural Products Communication, 11(9), 1297 (2016).

10. P.T. Motsumi, T. Qwebani-Ogunleye, I.P. Ejidike, F.M. Mtunzi, Z. Nate, Rasayan Journal of Chemistry, 13(1), 423(2020), DOI:10.31788/RJC.2020.1315594

11. T. Juwitaningsih, I.S. Jahro, S.A. Sari, Y. Rukayadi, Research Journal of Chemistry and Environment, 24(1), 99(2020)

12. O.O. Igbinosa, E.O. Igbinosa, O.A. Aiyegoro, African Journal of Pharmacy and Pharmacology, 3(2), 58(2009)

13. P. Molyneux,Songklanakarin Journal of Science and Technology, 26(2), 211(2003)

14. H. Soltanzadeh, L. Acik, M. Turk, M. Houshmand, G. Shahsavari,Gazi Medical Journal,29(3), 264(2018), DOI:10.12996/gmj.2018.75

15. W.W. Davis, T.R. Stout,Applied Microbiology, 22(4), 659(1971)

16. S. Maji, P. Dandapat, D. Ojha, C. Maity, S.K. Halder, P.K. Das Mohapatra, T.K. Pathak, B.R. Pati, A. Samanta, K.C. Mondal, Journal of Phytology, 2(4), 57 (2010)

17. J. Dzoyem, A. NKuete, V. Kuete, M.F. Tala, H.K. Wabo, S.K. Guru, V.S. Rajput, A. Sharma, P. Tane, I.A. Khan, A.K. Saxena, H. Laatsch, N.H. Tan, Planta Medica, 78(8), 787(2012), DOI: $10.1055 / \mathrm{s}-0031-1298431$

18. M. Jun, H.Y. Fu, J. Hong, X. Wan, C.S. Yang, C.T. Ho, Journal of Food Science, 68(6), 2117(2003), DOI: $10.1111 / j .1365-2621.2003 . t b 07029 . x$

19. S.B. Sarbadhikary, S. Bhowmik, B.K. Datta, N.C. Mandal,. International Journal of Current Microbiology and Applied Sciences, 4(8), 643(2015)

20. M.A.C. Galves, International Journal of Scientific and Research Publication, 5(12), 440(2015)

21. M. Suffness, J.M. Pezzuto,Methods for Plant Biochemical Assays and Bioactivity, 6, 71(1990)

22. F. Lohézic-Le Dévéhat, A. Bakhtiar, C. Bézivin, M. Amoros, J. Boustie,Fitoterapia, 73(5), 400(2002)

23. D. Susanti, H.M. Sirat, F. Ahmad, R.M. Ali, N. Aimi, M. Kitajima, Food Chemistry, 103(3), 710(2007), DOI:10.1016/J.FOODCHEM.2006.09.011

24. V. Kumar, P.C. Bhatt, M. Rahman, D.K. Patel, N. Sethi, A. Kumar, N.K. Sachan, G. Kaithwas, F.A. Al-abbasi, F. Anwar, A. Verma, BMC Complementary Medicine and Therapies, 16(1), 510(2016), DOI: 10.1186/s12906-016-1470-9

25. R.H. Thomson, The Chemistry of Natural Products. 2nd ed. Springer (1993)

26. H. Diastuti, Y.M. Syah, L.D. Juliawaty, M. Singgih, ALCHEMY Jurnal Penelitian Kimia, 12(2), 103(2016), DOI:10.20961/alchemy.12.2.1726.103-111

27. P. Daisy, S. Mathew, S. Suveena, N.A. Rayan, International Journal of Biomedical Science, 4(3), 196(2008)

28. M. Saleem, M. Nazir, M.S. Ali, H. Hussain, Y.S. Lee, N. Riaz, A. Jabbar, Natural Product Reports, 27(2), 238(2010), DOI:10.1039/b916096e

[RJC-56143/2019] 